\title{
Variations
}

Variations

Revue internationale de théorie critique

$17 \mid 2012$

Critique du travail

\section{En matière de révolte, aucun de nous ne doit avoir besoin d'ancêtres}

Maud Ingarao

\section{(2) OpenEdition}

Journals

Édition électronique

URL : http://journals.openedition.org/variations/406

DOI : 10.4000/variations.406

ISSN : 1968-3960

Éditeur

Les amis de Variations

Référence électronique

Maud Ingarao, "En matière de révolte, aucun de nous ne doit avoir besoin d'ancêtres », Variations [En ligne], 17 | 2012, mis en ligne le 15 octobre 2012, consulté le 15 septembre 2020. URL : http:// journals.openedition.org/variations/406

Ce document a été généré automatiquement le 15 septembre 2020

Les ami•e•s de Variations 


\section{En matière de révolte, aucun de nous ne doit avoir besoin d'ancêtres}

\section{Maud Ingarao}

En matière de révolte, aucun de nous ne doit avoir besoin d'ancêtres. (André Breton cité par Annie Le Brun, "Changer la vie » ou le plus difficile à imaginer, 18 août 2012, http://www.pauljorion.com/blog/?p=40589)

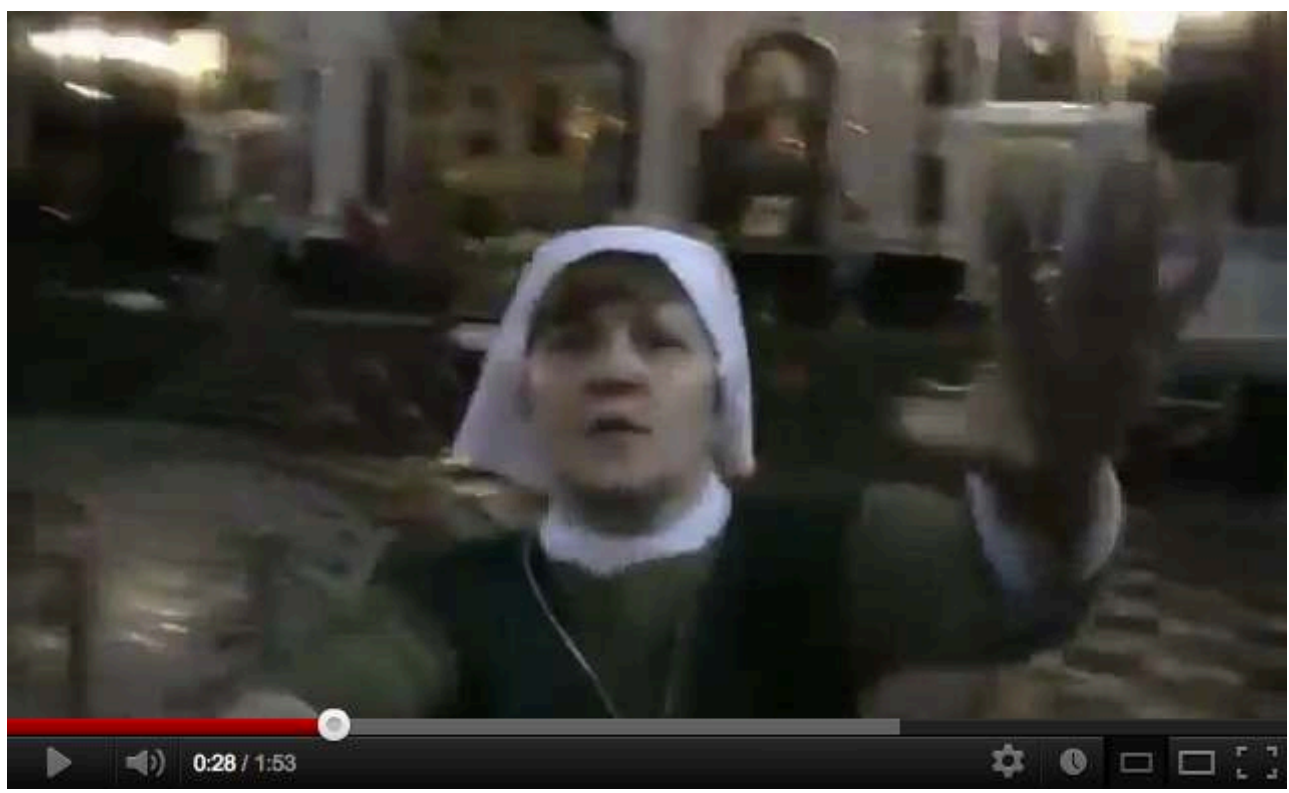

Femme vêtue d'un costume dans la Cathédrale du Christ-Sauveur de Moscou le 21 février 2012. Image citée de la vidéo http://www.youtube.com/watch?v=YrOjNui5Qw8 
INDEX

Mots-clés : critique du travail, correspondance, artistes, socialisme vert, travailleurs culturels, Wertkritik, Gorz André, dialogue, Vincent Jean-Marie, écologie, modèles alternatifs, Marx Karl, penser le Capital, ethos du travail, Eglise Orthodoxe, salariat, domination 